Т.М. СОБЧЕНКО

\title{
ПІДГОТОВКА МАЙБУТНІХ ПЕДАГОГІВ ДО ІННОВАЦІЙНОЇ ПРОФЕСІЙНОЇ ДІЯЛЬНОСТІ
}

(C) Собченко Т.М., 2020

http://orcid.org/0000-0002-9213-5556

http://doi.org/10.34142/2312-2471.2020.63.17

Стаття присвячена проблемі підготовки майбутніх педагогів до інноваційної професійної діяльності. Місце інноваційної діяльності в організації сучасної вищьої освіти зумовлено закономірним розвитком педагогічної теорії, зміною сочіальних та політичних умов, які спрямовані на поліпшення якості освіти. Таким чином, грунтовні зміни в освіті вимагають змін та корегування фундаментальних основ педагогіки, освітніх процесів та технологій. Здійснення якісної професійної підготовки майбутніх вчителів вимагає необхідності розроблення та впровадження в освітній процес інноваційного інструментарію. У статті проаналізовано та узагальнено різноманітні дефініції «інновації» та «нововведення». Зокрема, зазначено, щуо інновачії виникають тодi, коли є певна нова ідея, яка впроваджується, й цим самим тягне за собою істотні зміни та перетворення. Щодо поняття «нововведення» з'ясовано, щуо останнє є процесом, який має на меті змінити систему освіти, щуо здійснюється свідомо $і$ навмисно, з метою поліпшення системи. Підкреслено, щзо у своєму розвитку нововведення має пройти певні етапи. Якщу якийсь з цих етапів не пройдений, то нововведення вважається незавершеним. Також виділено складники освітніх інновацій, а саме: педагогічний, науково-виробничий та сочіально-економічний. Представлено та узагальнено погляди вітчизняних науковців щуодо визначення готовності майбутніх педагогів до інновачиійнї педагогічної діяльності. Охарактеризовано структурні компоненти готовності до інноваційній діяльності: мотивачійний, когнітивний, рефлексивний, креативний. Окреслено показники, які визначають готовність педагога до інноваційної діяльності. Готовність майбутнього вчителя до інновачійної діяльності зумовлена

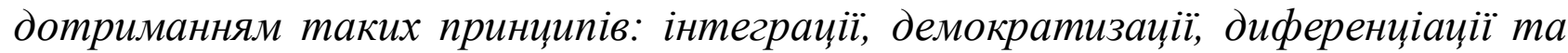
індивідуалізаиіі освіти. Також визначено основні професійні та особисті якості, яких набуває майбутній вчитель у прочесі підготовки до інновачійної педагогічної діяльності. Висновками та подальшими перспективами $\epsilon$ виділення основних аспектів підготовки майбутніх педагогів до інноваційної педагогічної діяльності та розробка курсів за вибором «Інновації в освіті», «Педагогічні студї̈, метою яких є формування у здобувачів освіти потреб професійного розвитку та підготовка до професійної інноваційної діяльності.

Ключові слова: інновачії, нововведення, інновачійна діяльність, здобувачі вищуӧ освіти, освітній прочуес. 


\section{Sobchenko T.M. Future Teachers' Preparation for Innovative Professional Activity}

The article is devoted to the problem of future teachers' preparation for innovative professional activity. The place of innovative activity in the organization of modern higher education is correlated to the natural development of pedagogical theory, changes in social and political conditions, which are aimed at improving the education quality. That's why fundamental changes in the education require changes and adjustments to the fundamentals of pedagogy, processes and technologies. The implementation of high-quality professional training of future teachers requires the need to develop and implement innovative tools in the educational process. The article analyzes and summarizes various definitions of "innovation" and "implementation". In particular, it is noted that innovations arise when a certain new idea appears that is implemented and thus entails significant changes and transformations. As for the concept "implementation", it has been found that the latter is a process that targets to change the education system, which is carried out consciously and intentionally in order to improve the system. It is emphasized that in its development innovation must pass certain stages. If any of these stages are not passed, the innovation is considered incomplete. There are also components of educational innovations, namely: pedagogical, research and production and socioeconomic. The views of national scientists on determining the readiness of future teachers for innovative pedagogical activities are presented and generalized. The structural components of readiness for innovative activity are characterized: motivational, cognitive, reflexive, creative. Indicators that determine the readiness of a teacher to innovate are outlined. The readiness of a future teacher to innovate is connected to the following principles: integration, democratization, differentiation and individualization of education. The main professional and personal qualities that a future teacher acquires in the process of preparation for innovative pedagogical activity are also determined. Conclusions and further prospects are the selection of the main aspects of training future teachers for innovative pedagogical activities and the development of elective courses "Innovation in Education", "Pedagogical Studies", which aim to form students' needs for professional development and preparation for professional innovation.

Key words: innovations, implementation, innovative activity, students in higher education, educational process.

Постановка проблеми. Стратегічна освітня реформа в Україні спрямована на підвищення якості освіти на всіх рівнях ії здобуття. Провідною позицією перебудови системи освіти $є$ створення умов для формування відповідних компетентностей у здобувачів освіти. У Законі України "Про вищу освіту” зазначено, що компетентності є “динамічним поєднанням знань, умінь та навичок, практичні ноу-хау; способи мислення; професійні, світоглядні та громадянські якості; морально-етичні цінності, що визначають здатність людини успішно здійснювати професійну та подальшу навчальну діяльність, i це результат виховання на певному рівні вищої освіти” [5]. 
Так, метою «Концепції розвитку педагогічної освіти» (виконавче розпорядження Міністерства освіти і науки України №776 від 16 липня 2018 року) $\epsilon$ вдосконалення системи педагогічної освіти для створення бази підготовки педагогічних працівників нової генерації [10].

Очевидно, що саме педагогічним закладам вищої освіти відводиться важлива роль у контексті зазначеної проблеми. Надзвичайно швидкий розвиток прогресивних технологій, які семимильними кроками впевнено йдуть вперед, спонукають педагогів до мобільності, інноваційного розвитку та оволодіння сучасними високими технологіями.

Тому здійснення якісної професійної підготовки майбутніх вчителів у закладах педагогічної вищої освіти вимагає суттєвих змін підходу до здійснення ефективної організації освітнього процесу. Ці орієнтири мають бути спрямовані на розвиток критичного мислення, творчої винахідливості, формування інноваційної компетентності майбутніх педагогів.

Аналіз останніх досліджень і публікацій. Напрями розвитку освітньої інноватики стали предметом посиленої уваги науковців (В.Взятишева, В.Пінчука, О.Попової, А.Пригожина) у кінці минулого століття. У дослідженнях та публікаціях вчених (Л.Березівської, Л.Даниленко, І.Дичківської, Н.Юсуфбекової) висвітлено проблеми впровадження педагогічних інновацій у заклади середньої освіти. Проблеми підготовки вчителя до інноваційної діяльності розкрито у працях (І.Авдєєвої, І.Гавриш, О.Євдокімової, А.Литвинова, О.Огієнко, І.Співакової).

Виділення невирішених раніше частин загальної проблеми. Однак, у контексті масштабних нововведень в освітній процес питання підготовки майбутніх педагогів до інноваційної діяльності та формування в них інноваційної компетентності наразі залишається недостатньо вирішеним та вимагає як теоретичного, так і практичного обгрунтування.

Мета статті - на основі аналізу науково-педагогічної літератури й узагальнення досвіду підготовки спеціалістів у закладах вищої освіти виділити основні аспекти підготовки майбутніх педагогів до інноваційної педагогічної діяльності.

Виклад основного матеріалу. Засобом вирішення актуальних освітніх завдань у контексті грунтовних реформ у системі освіти $\epsilon$ інноваційна діяльність. Аналізуючи наявність різноманітних дефініцій «інновації» та «нововведення», виникає необхідність зведення та узагальнення поглядів сучасних вчених, тобто виокремлення найбільш розгорнутих визначень (див. табл.1).

ВИЗНАЧЕННЯ ПОНЯТТЯ «ІННОВАЦЇ̈» ТА «НОВОВВЕДЕННЯ»

\begin{tabular}{|c|c|c|}
\hline № & Інновації & Нововведення \\
\hline 1. & $\begin{array}{c}\text { О.Попова [13; с.14]: } \\
\text { «цілеспрямований і керований } \\
\text { процес внесення змін в освітню } \\
\text { практику шляхом створення. }\end{array}$ & $\begin{array}{c}\text { А.Пригожин [13; с.11]: } \\
\text { «...цілеспрямована зміна, яка } \\
\text { вносить в середовище впровадження } \\
\text { (організашію. поселення. суспільство }\end{array}$ \\
\hline
\end{tabular}




\begin{tabular}{|c|c|c|}
\hline & $\begin{array}{c}\text { розповсюдження та освоєння } \\
\text { новацій...». }\end{array}$ & $\begin{array}{c}\text { тощо) нові, відносно стабільні } \\
\text { елементи...». }\end{array}$ \\
\hline 2. & $\begin{array}{c}\text { А.Найн [13]:»...принципово нове } \\
\text { утворення, нова ідея, яка істотно } \\
\text { змінює технологію навчання, } \\
\text { новий тип навчального закладу } \\
\text { або управління освітою». }\end{array}$ & $\begin{array}{c}\text { К. Ангеловських [1]: «...спроба } \\
\text { змінити систему освіти, що } \\
\text { здійснюється свідомо і навмисно, з } \\
\text { метою поліпшення системи, що вже } \\
\text { функціонує...». }\end{array}$ \\
\hline 3. & $\begin{array}{c}\text { М.Кларін [6]: «...відноситься не } \\
\text { просто до створення та } \\
\text { поширення нововведень, але і до } \\
\text { таких змін, які носять істотний } \\
\text { характер, супроводжуються } \\
\text { змінами в образі діяльності, } \\
\text { стилі, мислення...». }\end{array}$ & $\begin{array}{c}\text { М.Лапін [7]: «...свідоме введення і в } \\
\text { основних рисах відтворення } \\
\text { (тиражування), зміна структури та } \\
\text { (або) процесу функціонування } \\
\text { соціотехнічної системи, як елементу } \\
\text {..і відповідають як } \\
\text { закономірностям розвитку } \\
\text { суспільства, так і внутрішнім } \\
\text { законам розвитку змінюваного } \\
\text { об’єкту». }\end{array}$ \\
\hline 4. & $\begin{array}{c}\text { Л.Даниленко [2]: «кінцевий } \\
\text { продукт застосування новизни з } \\
\text { метою зміни об’єкта управління } \\
\text { й забезпечення економічного, } \\
\text { соціального, науково-технічного, } \\
\text { екологічного та іншого ефекту». }\end{array}$ & $\begin{array}{c}\text { Н.Юсуфбекова [14]: «це не явище, а } \\
\text { процес, спрямований на досягнення } \\
\text { певної мети». }\end{array}$ \\
\hline
\end{tabular}

Отже, ватро зазначити, що автори мають різні визначення цих понять. Інновації, на нашу думку, це процес оновлення та реформування освіти. Вони виникають тоді, коли є певна нова ідея, яка впроваджується й цим самим тягне за собою істотні зміни та перетворення. Тому що зміст будь-якої інновації у певному сенсі протирічить сталим традиціям. Відповідно трансформування завжди породжує щось нове.

Щодо поняття «нововведення», ми поділяємо думку К.Ангеловських, та вважаємо, що нововведення $є$ процесом, який має на меті змінити систему освіти, що здійснюється свідомо і навмисно, з метою поліпшення системи. У своєму розвитку нововведення має пройти усі етапи:

- зародження (усвідомлення потреби змін);

- освоєння (експеримент, упровадження створених змін);

- дифузія (багаторазове повторення нововведення в інших умовах, його поширення);

- рутинізація (реалізація нововведення у стабільних елементах, які постійно функціонують).

Структурним елементом «інновацій» $\epsilon$ освітні інновації, які мають наступні складники: педагогічний, науково-виробничий та соціальноекономічний. 
Освітні інновації, на думку Л.Даниленко, (2003) - це вдосконалені чи нові освітні, дидактичні, виховні, управлінські системи або їх компоненти; освітні технології, що суттєво поліпшують результати освітньої діяльності [2].

За компонентами освітнього процесу освітні інновації поділяються на:

- педагогічні (навчальні та виховні);

- організаційні (управлінські).

За масштабністю упровадження у освітній процес виділяють масштабні (якісно змінюють мету, завдання, зміст та структуру освітнього процесу) та локальні (оновлюють форми, методи, засоби навчання, виховання, управління).

На сучасному етапі реформування національної системи освіти освітні інновації здійснюються через:

- зміст навчання та виховання (розроблення та впровадження Концепції «Нова українська школа»; запровадження Державних стандартів початкової освіти, проєктів Державних стандартів загальної, середньої, вищої освіти; широкий спектр вибору авторських програм, навчальних планів, підручників тощо);

- форми, методи, технології навчання та виховання (використання інтерактивних методів навчання та виховання; впровадження змішаної та дистанційної форм навчання тощо);

- зміст, форми і методи управління закладом освіти (запровадження управлінських функцій керівника та різні види моніторингу за їх виконанням, використання економічних методів управління тощо).

Усі сфери освіти досить тісно пов'язані між собою, тому будь-яке нововведення в одній сфері обов'язково вплине на інші.

На наш погляд, цікавою та цінною для нашого дослідження $є$ думка О.Свдокімової, Н.Алексєєнко, які вважають, що обов'язковою компетенцією фахівця є саме інноваційна, без наявності якої унеможливлюється ефективне виконання професійної діяльності особистістю, оскільки потребує від неї готовності до змін у зв'язку з постійними нововведеннями та модернізаціями, що відбуваються в суспільстві $[4$, с. 146].

На думку А.Литвинова, (2019) готовність до інноваційної педагогічної діяльності - це особливий особистісний стан, який передбачає наявність у педагога мотиваційно-ціннісного ставлення до професійної діяльності, володіння ефективними способами і засобами досягнення педагогічних цілей, здатності до творчості й рефлексії $[8$, с.22 с.]

І.Дичківська (2004) виділяє основні структурні компоненти готовності до інноваційній діяльності:

- мотиваційний (орієнтація та ставлення до здійснення педагогічної діяльності);

- когнітивний (результат пізнавальної діяльності);

- рефлексивний (здатність до самоаналізу);

- креативний (оригінальний, нестандартний підхід до вирішення педагогічних завдань) [3; с.17]. 
Н.Плахотнюк (2015) наголошує на необхідності впровадження навчальноігрового проектування в професійну підготовку майбутніх учителів для їх готовності до інноваційної діяльності [12, с.181-191].

Готовність педагога до розроблення, апробації та впровадження в навчально-виховний процес педагогічних інновацій $\epsilon$, на думку Р.Михайлишина (2016), необхідним компонентом його професійної діяльності $[9$, c.11-18].

А.Литвинов (2019) розглядає готовність до провайдингу інновацій як важливу професійну якість педагога та наголошує на необхідності поглибленого вивчення специфіки інновацій у сфері освіти. Він вважає, що готовність педагога до інноваційної діяльності слід визначати за таким показниками:

1. Усвідомлення ним потреби впровадження педагогічних інновацій у власну професійну діяльність.

2. Інформованість про новітні педагогічні технології, знання авторських методик.

3. Зоріснтованість на створення власних творчих завдань, методик, налаштованість на експериментальну діяльність.

4. Готовність до подолання труднощів, пов'язаних зі змістом та організацією інноваційної діяльності.

5. Володіння практичними навичками освоєння педагогічних інновацій та розроблення нових [8, с.25].

Інноваційна діяльність майбутнього вчителя базується на таких принципах: інтеграції, демократизації, диференціації та індивідуалізації освіти, дотримання яких визначає його готовність до інновацій.

Також вважаємо за необхідне визначити основні професійні та особистісні якості, які набуває майбутній вчитель у процесі підготовки до інноваційної педагогічної діяльності:

- передова педагогічна позиція;

- усвідомлення та прагнення до бажаного власного творчого пошуку;

- можливість відмови від стереотипів;

- уміння визначати індивідуальні здібності особистості та використовувати їх у процесі навчання;

- потреба у новизні;

- прагнення та спроможність до самовдосконалення та саморозвитку;

- застосування адекватних форм самооцінки та рефлексії;

- осмислення у нововведеннях власної мети та бажання іiі реалізувати;

- здатність до використання оригінальних та сучасних прийомів, методик, форм і методів інноваційного навчання 3 урахуванням власного досвіду.

На нашу думку, основними аспектами підготовки майбутніх педагогів до інноваційної педагогічної діяльності є такі:

- наявність команди фахівців, професіоналів, які мають забезпечувати якісну підготовку здобувачів вищої освіти із урахуванням запитів «нової 
української школи» та сучасних освітніх викликів, а також з орієнтиром на нові перспективні професії, зокрема, «андрагог», «тьютор», «модератор», «фасилітатор», «менеджер електронного навчання», «асистент вчителя» тощо;

- зміна підходу до здійснення ефективної організації освітнього, а саме: коригування та оновлення змісту навчальних програм, удосконалення форм та методів навчання, використання гейміфікації, розробка та впровадження вибіркових навчальних дисциплін із урахуванням запитів стейкхолдерів, застосування дуального навчання тощо.

Висновки. Проведений педагогічний пошук показав необхідність зміни підходу до здійснення ефективної організації освітнього процесу, коригування та оновлення змісту навчальних програм, а саме вдосконалення програми підготовки майбутніх педагогів до професійної діяльності та розробки курсів за вибором студентів «Інновації в освіті», та «Педагогічні студії», які спрямовані на підвищення рівня підготовки майбутніх педагогів до інноваційної професійної діяльності.

Перспективи подальших розвідок вбачаємо в розробці та впровадженні курсів «Інновації в освіті» та «Педагогічні студії» у процес навчання майбутніх учителів.

\section{Лimepamypa}

1. Ангеловских К. Учителя и инновации. Москва: Просвещение, 1991. $159 \mathrm{c}$.

2. Даниленко Л. Освітній менеджмент: навч. посіб. Київ: Шкільний світ, 2003. $400 \mathrm{c}$.

3. Дичківська I.M Інноваційні педагогічні технології: навч. посіб. Київ: Академвидав, 2004. 320 с.

4. Свдокимова О.О., Алексеєнко Н.В. Інноваційна компетентність як професійна важлива риса сучасного фахівця. Право і безпека. 2017. №2 . С. 146152.

5. Закон України про вищу освіту. Відомості Верховної Ради (ВВР), 2014, № 37-38, ст.2004. URL: https://zakon.rada.gov.ua/laws/show/392-20\#Text

6. Кларин М.В. Инновационные модели обучения в зарубежных педагогических поисках. Москва: Наука, 1994. 222 с.

7. Лапин Н.И. Актуальные проблемы исследования нововведений. Социальные факторы нововведений в организационных системах. Москва, 1980. C. 65-74.

8. Литвинов А.С. Педагогічний провайдинг інновацій в освіті: навч. посіб. /за заг.ред. В.В.Борисова. Суми. Університетська книга, 2019. 265 с.

9. Михайлишин Р. Професійна готовність педагога до інноваційної діяльності: якісний аспект: Вісник Львівського університету. Серія педагогічна. 2016. Вип.31. С. 11-18.

10. Наказ Міністерства освіти i науки «Про затвердження Концепції розвитку педагогічної освіти» (2018). URL: https://www.uzhnu.edu.ua/uk/infocentre/get/17105. Accessed 16 July 2018 
11. Огієнко О.І. Педагогічні науки: теорія, історія, інноваційні технології. 2013. № 7 (33) С. 154-162.

12. Плахотнюк Н.П. Критерії та показники рівня готовності майбутніх учителів до інноваційної діяльності. Збірник наукових праџь Слов'янського державного педагогічного університету. Ч. II. (5). С. 181-191.

13. Попова О.В. Становлення і розвиток інноваційних педагогічних ідей в Україні у ХХ ст.. Х.: «ОВС», 2001. 256 с.

14. Юсуфбекова Н.Р. Общие основы педагогической инноватики: Опыт разработки теории инновационных процессов в образовании. М., 1991. 92 с.

\section{References}

1. Angelovskih, K.(1991). Teachers and innovation [Uchitelya i innovatsii]. Moscow: Education. (in Russian).

2. Danylenko, L. (2003). Educational management [Osvitnii menedzhment]. Kyiv: School World. (in Ukrainian).

3. Dychkivska, I.M. (2004). Innovative pedagogical technologies. [Innovatsiini pedahohichni tekhnolohii]. Kyiv: Akademvydav, 2004. (in Ukraine).

4. Yevdokimova, O.O.,\& Aleksieienko, N.V. (2017). Innovative competence as a professionally important feature of a modern specialist [Innovatsiina kompetentnist yak profesiino vazhlyva rysa suchasnoho fakhivtsia]. Law and security, 2, $146-152$. (in Ukrainian).

5. Law of Ukraine (2019). Pro vyschchu osvitu [About higher education]. Retrieved from https://zakon.rada.gov.ua/laws/show/392-20\#Text (in Ukrainian).

6. Klarin, M.V. (1994). Innovative teaching models in foreign pedagogical searches [Innovatsionnyie modeli obucheniya $\mathrm{v}$ zarubezhnyih pedagogicheskih poiskah]. Moscow: Nauka. (in Russian).

7. Lapin, N.I. (1980). Actual problems of research of innovations [Aktualnyie problemyi issledovaniya novovvedeniy] Social factors of innovations in organizational systems. Moscow. (in Russian).

8. Litvinov, A.S. (2019). Pedagogical provision of innovations in education [Pedahohichnyi provaidynh innovatsii v osviti: navch. posib.] / ed. by V.V. Borisova. Sumy: University book. (in Ukrainian).

9. Mykhailyshyn, R. (2016). Professional readiness of a teacher for innovative activity: qualitative aspect [Profesiina hotovnist pedahoha do innovatsiinoi diialnosti: yakisnyi aspekt]. Visnyk of Lviv National University. Pedagogical Series, 31, 11-18. (in Ukrainian).

10. Order of the Ministry of Education and Science. (2018). Pro zatverdzhenij Koncepciï rozvitku pedagogichnoiii osvity [On approval of the Concept of teacher education development]. Retrieved from https://www.uzhnu.edu.ua/uk/infocentre/get/17105. Accessed 16 July 2018 (in Ukrainian).

11. Ogienko, O.I. (2013). Pedagogical sciences: theory, history, innovative technologies [Pedahohichni nauky: teoriia, istoriia, innovatsiini tekhnolohii]. (in Ukrainian). 
12. Plahotniuk, N.P. (2010). Criteria and indicators of the level of readiness of future teachers for innovation [Kryterii ta pokaznyky rivnia hotovnosti maibutnikh uchyteliv do innovatsiinoi diialnosti]. Collection of scientific works of Sloviansk State Pedagogical University, II(5), 181-191. (in Ukrainian).

13. Popova, O.V. (2001). Formation and development of innovative pedagogical ideas in Ukraine in the twentieth century [Stanovlennia i rozvytok innovatsiinykh pedahohichnykh idei v Ukraini u KhKh st.: monohrafiia] Kharkiv: "OVS". (in Ukrainian).

14. Yusufbekova, N.R. (1991). General foundations of pedagogical innovation: Experience in developing the theory of innovative processes in education [Obschie osnovyi pedagogicheskoy innovatiki: Opyit razrabotki teorii innovatsionnyih protsessov v obrazovanii]. Moscow. (in Russian). 